IJTC

Ilomata International Journal of Tax \& Accounting

P-ISSN: 2714-9838; E-ISSN: 2714-9846

\title{
Bankruptcy Analysis Using Altman Z-Score Model and Springate Model In Retail Trading Company Listed In Indonesia Stock Exchange
}

\author{
Erni Prasetiyani ${ }^{1}$, Mohammad Sofyan ${ }^{2}$ \\ ${ }^{12}$ Institut Ilmu Sosial dan Manajemen Stiami \\ Correspondent: erni@stiami.ac.id \\ Submitted : June 23, 2020 Revised : July 15, 2020 Published : July 30,2020
}

\begin{abstract}
The business environment in the retail experience turbulence, strong now many companies to reduce the impact outlets greater losses. Reduction in earnings a problem most of all, and this has potential in bankruptcy retail company in the future This research is analyzing about retail companies affected by the deterioration in performance that has been registered in Indonesia Stock Exchange. Model and data processing used to calculate potential harm is a model altman z score and models springate. Discussion result there is a retail companies go public has the potential to be the calculated use bankruptcy model altman z score as well as a model springate namely PT Modern International. Information, proceedings in potential for bankruptcy at annual report is not disclosure, was recommended to the stakeholders to oblige any new issuers give this information in the annual financial report made that release every year. To be accurate information and credible over the companies condition the truth.
\end{abstract}

Keyword: Altman Z-Score, Springate, TATO, ROE, ROA, NPM, Market to book value

\section{INTRODUCTION}

By the end of the third quarter of 2008, the intensity of the crisis grew with the collapse of the largest US investment bank Lehman Brothers, which was followed by increasingly severe financial difficulties in a number of large-scale financial institutions in the United States, Europe and Japan. The global financial crisis has affected the Indonesian economy as reflected by the turmoil in the Capital Market and Money Market (BI, 2009).

For measuring the financial health of a business firm with Altman's Z-score to predict possibilities of bankruptcy. Altman (1968) defines five predicted factors that can be used to test the validity of Multivariate model. Using financial ratios to predict bankruptcy can be accurate up to $90 \%$ (Chen \& Shimerda, 1981). Any several other models have been introduced to predict bankruptcy such as Springate (1978); Ohlson (1980); Zmijewski (1983); and Grover and Lavin (2001). In predicting the bankcruptcy, these models have different levels of accuracy based on their measurements used (Purnajaya and Merkusiwati, 2014).

Retail trading companies are currently struggling in a defensive position in the industrial era 4.0 or innovative disruptive. With the condition of Public Go performance, Retail Company is increasingly declining. The writer detects bankruptcy potential is a condition which the company is unable to operate the company properly because of the very severe in financial difficulties experienced (Dwiprihantini, 2014). 
Bankruptcy Analysis Using Altman Z-Score Model and Springate Model In Retail Trading Company Listed In Indonesia Stock Exchange

Prasetiyani \& Sofyan

Table 1.

The Financial Performance of Retail Trading Company Listed In Indonesia Stock Exchange 2013-2018

\begin{tabular}{lccccc}
\hline \multicolumn{1}{c}{ Company Name } & TATO & ROE & ROA & NPM & $\begin{array}{c}\text { Market to } \\
\text { book value }\end{array}$ \\
\hline PT Matahari Dept. Store, Tbk & 2,1229 & 0,3920 & 0,2029 & 0,0953 & 90,7268 \\
\hline PT Hero Supermarket Tbk & 1,7411 & 0,0457 & 0,0203 & 0,0121 & 41,5167 \\
\hline PT Ramayana Lestari Sentosa Tbk & 0,6386 & 0,0594 & 0,0430 & 0,0336 & 10,1833 \\
\hline PT Mitra Adiperkasa Tbk & 1,3294 & 0,0849 & 0,0293 & 0,0226 & 10,6733 \\
\hline PT Modern International Tbk & 0,5362 & 0,2801 & $(0,2477)$ & $(0,8952)$ & 4,2050 \\
\hline PT Matahari Putra Prima, Tbk & 2,0142 & $(0,0939)$ & 0,0009 & 0,0033 & 33,0033 \\
\hline
\end{tabular}

(Data Source : Approximately 6 years)

If we see the conditions based on the data above, how big the bankruptcy potential of the Public Retail Company Going is, along with the decline in financial performance and in the stock market value of the Go Public Retail Company over the period from 2013 to 2018 by using the Altman Z-Score theory and the Springate's Model.

This study aims to provide information about the Go Public Retail Companies bankruptcy potential to the stakeholders. Furthermore, Effendi, et al (2016) used the bankruptcy prediction model of the Springate to estimate the stock prices of the telecommunication companies, while Andriawan and Salean (2016) used the Almant model and analyzed its impact to the pharmacy company's stock prices. Adrian and Khoiruddin (2014) applied the Almant model and analyzed its impact to the manufacturing company's stock prices.

\section{METHOD}

The data is in the form of Go Public Retail Company financial reports obtained through the website from www.IDX.co.id or the Indonesia Stock Exchange and has been audited by the public accountant. The range of financial statement data is over the period of December 31, 2013 to December 31, 2018. Types of data are internal data with quantitative data classification released by Go Public trade retail companies.

\section{Data Processing Techniques}

The Calculation of potential bankruptcy using the Altman Z Score and Springate's Model.

The Altman Z Score Data Process Model:

$\mathrm{X} 1$ (Working Capital) $=$ Current assets - Current liabilities) $/$ Total assets

X2 (Return Earning on Assets) = Retained earnings / total assets

X3 (Return on Assets) = Profit before interest and tax / Total assets

X4 (Market Value of Shares on Net Book Value of Liabilities) = Market value of ordinary and preferred shares / Total book value of liabilities

X5 (Total Assets Turn Over) $=$ Sales / Total assets

Springate's Data Process Model:

A $($ Working Capital $)=$ Working capital / Total assets

$\mathrm{B}$ (Return On Assets) = Net profit before interest and tax / Total assets

C $($ EBT on Current Liabilities $)=$ Net profit before tax / current liabilities

$\mathrm{D}($ Total Assets Turn Over $)=$ Sales $/$ Total assets 
Bankruptcy Analysis Using Altman Z-Score Model and Springate Model In Retail Trading Company Listed In Indonesia Stock Exchange

\section{RESULT AND DISCUSSION}

Table 2.

The Prediction Result of Altman Z-Score and Springate's

\begin{tabular}{|llcccc}
\hline No & \multicolumn{1}{c}{ Company } & $\begin{array}{c}\text { Altman Z- } \\
\text { Score }\end{array}$ & Prediction & Springate's & Prediction \\
\hline $\mathbf{1}$ & $\begin{array}{l}\text { PT. Matahari Putra } \\
\text { Prima }\end{array}$ & 2,648 & Grey Area & 0,818 & $\begin{array}{c}\text { Potentially } \\
\text { Bankrupt }\end{array}$ \\
\hline $\mathbf{2}$ & $\begin{array}{l}\text { PT. Modern } \\
\text { International }\end{array}$ & $-1,370$ & $\begin{array}{c}\text { Potentially } \\
\text { Bankrupt }\end{array}$ & $-0,993$ & $\begin{array}{c}\text { Potentially } \\
\text { Bankrupt }\end{array}$ \\
\hline $\mathbf{3}$ & PT. Mitra Adi Perkasa & 2,535 & Grey Area & 1,062 & No Potential \\
\hline $\mathbf{4}$ & PT. Hero & 2,431 & Grey Area & 0,613 & $\begin{array}{c}\text { Potentially } \\
\text { Bankrupt }\end{array}$ \\
\hline $\mathbf{5}$ & PT. Ramayana Lestari & 3,345 & $\begin{array}{c}\text { No } \\
\text { Potential } \\
\text { No }\end{array}$ & 1,520 & No Potential \\
\hline $\mathbf{6}$ & $\begin{array}{l}\text { PT. Matahari Dept. } \\
\text { Store }\end{array}$ & 7,622 & $\begin{array}{c}\text { Potential } \\
\text { S }\end{array}$ & & Non Potential \\
\hline
\end{tabular}

Source: Data Research in 2019

\section{The Calculation Results Using The Altman Z-Score Method}

Clarification of a healthy and bankrupt company is based on the Altman Z-score value, namely:

1. $Z$ value $<1.81$, including a bankrupt company

2. Value $1.81<Z<2.99$, including the gray area (cannot be determined whether the company is healthy or bankrupt)

3. $Z$ value $>2.99$, including non-bankrupt companies

The Bankruptcy Prediction Calculation:

The calculations results of PT Matahari Putra Prima over the past 6 years found an average value of 2.648. This value is between $1.81<2.648<2.99$, including the gray area (cannot be determined whether the company is healthy or bankrupt). PT Modern International over the past 6 years found an average value of $-1,370$. This value is $<1.81$, including the bankrupt company. PT Mitra Adi Perkasa over the past 6 years found an average value of 2.535. This value is between $1.81<2.535<2.99$, including the gray area (cannot be determined whether the company is healthy or bankrupt). PT Hero for the last 6 years found an average value of 2,431. This value is between $1.81<2,431<2.99$, including the gray area (cannot be determined whether the company is healthy or bankrupt). PT Ramayana Lestari over the past 6 years found an average value of 3.345. This value $>2.99$, including the non-bankrupt companies. And PT Matahari Dept. Store for the last 6 years found an average value of 3,345 . This value $>2.99$, including the non-bankrupt companies.

\section{The Calculation Results With Springate's Method}

The Clarification of a healthy and bankrupt company is based on the S-score of the Springate method, namely:

1. S score $>0.862$ is a company that does not have the potential to go bankrupt.

2. S score $<0.862$ is classified as an unhealthy and potentially bankrupt company.

The Bankruptcy Prediction Calculation:

The calculations results of PT Matahari Putra Prima over the past 6 years found an average value of 0.818 . This value $<0.862$ is classified as an unhealthy and potentially bankrupt company. PT Modern International over the past 6 years found an average value of -0.993 . This value $<$ 0.862 is classified as an unhealthy and potentially bankrupt company. PT Mitra Adi Perkasa over the past 6 years found an average value of 1.062 . This value $>0.862$ is classified as a company that 
Bankruptcy Analysis Using Altman Z-Score Model and Springate Model In Retail Trading Company Listed In Indonesia Stock Exchange

Prasetiyani \& Sofyan

has no potential to go bankrupt. PT Hero for the last 6 years found an average value of 0.613 . This value $<0.862$ is classified as an unhealthy and potentially bankrupt company. PT Ramayana Lestari over the past 6 years found an average value of 1.520. This value $>0.862$ is classified as a company that has no potential to go bankrupt. And PT Matahari Dept. Store for the last 6 years found an average value of 3.003. This value $>0.862$ is classified as a company that has no potential to go bankrupt.

The calculation of PT. Matahari Putra Prima (MPPA) produced different predictions. Altman calculation results are in an area that cannot be determined whether the company is bankrupt or not in the future (gray area). Meanwhile, according to Springate's calculations, it predicted bankruptcy. Because in the third quarter of 2018, MPPA posted a loss of Rp 335 billion, below from the company's loss in the same period of the previous year which was Rp 385 billion (Putri, 2018). Whereas in the third quarter of 2019, MPPA's net sales still fell by $19.8 \%$ Year on Year (YOY) to Rp 6.64 trillion (Intan, 2019). PT. Modern International, Tbk, both methods predict bankruptcy. This company was unable to meet its obligations when it was billed because it had experienced a negative number (Handayani \& Andrianingsih, 2019). PT. Mitra Adi Perkasa produced different predictions. Altman calculation results are in the gray area or the financial condition requires special attention (Anissa, 2016). Meanwhile, according to the results of Springate, it is predicted not to go bankrupt. PT. Hero produced different predictions. Altman calculation results are in the gray area. Meanwhile, according to Springate's, it is predicted bankruptcy. The cause of bankruptcy is because the company's financial performance has been weak since the third quarter of 2018 which caused termination of employment about 532 employees until the third quarter of 2018. Not only that, 26 Giant retail outlets also stopped operating (Tristiawati, 2019). And PT. Ramayana Lestari and PT. Matahari Dept. Store, both methods predict bankruptcy. It shows that the financial condition of the two companies is in good health and it is unlikely that the company will experience bankruptcy (Rahmatullah, Sunarya, \& Jhoansyah, 2019).

\section{CONCLUSION}

Based on this discussion, it is known that the Altman Z-score calculation results show that there is 1 company that will go bankrupt, namely PT Modern International, while Springate's predicts that 3 companies will go bankrupt, namely PT Matahari Putra Prima, PT Modern International, and PT Hero, as shown in table 4.14 below:

Table 4. 1.

Number of Prediction Comparison Results

\begin{tabular}{lccrc}
\hline \multirow{2}{*}{ Method } & \multicolumn{2}{c}{ Result } & $\begin{array}{c}\text { Number of } \\
\text { Companies }\end{array}$ \\
\cline { 2 - 4 } & Go Bankrupt & Grey Area & No Potential & 6 \\
\hline Altman Z-Score & 1 & 3 & 2 & 6 \\
\hline Springate's & 3 & 0 & 3 & \\
\hline
\end{tabular}

The annual financial statements of Go Public companies do not present the potential bankruptcy. It can have a negative impact on investors and stakeholders because there is no disclosure of information. In the industry era 4.0 or disruptive era which the life cycle of an industry does not take place normally, it is recommended that industries affected are required to make a potential bankruptcy analysis with special parameters determined by the decision makers, in this case we can say the Financial Services Authority (OJK). 
Bankruptcy Analysis Using Altman Z-Score Model and Springate Model In Retail Trading Company Listed In Indonesia Stock Exchange

Prasetiyani \& Sofyan

Further studies can conduct similar research, and compared with different types of companies, so as to provide wider results related to Altman Z Score and Springate's Model

\section{REFERENCE}

Altman, E. (1968). Financial Ratios, Discriminant Analysis and the Prediction of Corporate Bankruptcy. The Journal of Finance, 23(4), 589-609. doi:10.2307/2978933.

Anissa, N. (2016). Penggunaan Metode Z-Score Untuk Memprediksi Kemungkinan Kebangkrutan Pada PT. Mitra Adi Perkasa, Tbk. Jurnal Ekonomi Bisnis, 21(3), 209-215. Retake from https://ejournal.gunadarma.ac.id/index.php/ekbis/article/view/1520.

Bower, C. M. (1995). Disruptive Tecnologies Catching the Wave. Harvard Business Review.

Chen, K., \& Shimerda, T. (1981). An Empirical Analysis of Useful Financial Ratios. Financial Management, 10(1), 51-60. Retrieved August 3, 2020, from www.jstor.org/stable/3665113.

Grover, J., \& Lavin, A. (2001). Financial Ratios, Discriminant Analysis and The Prediction of Corporate Bankruptcy: a Service Industry Extension of Altman's Z-Score Model of Bankruptcy Prediction. Working Paper. Southern Finance Assosiation Annual Meeting.

Handayani, M. O., \& Andrianingsih, V. (2019). Model Altman, Springate dan Zmijewski untuk Memprediksi Probabilitas Kebangkrutan (Studi Kasus Sektor Perusahaan Property yang Terdaftar di BEI Periode 2014-2018). Seminar Nasional Optimalisasi Sumberdaya Lokal di Era Revolusi Industri 4.0, (hal. 331-341).

Intan, K. (2019, November 11). Matahari Putra Prima (MPPA) membidik perbaikan profitabilitas hingga akbir tabun. Diambil kembali dari kontan.co.id: https://investasi.kontan.co.id/news/matahari-putra-prima-mppa-membidik-perbaikanprofitabilitas-hingga-akhir-tahun

Ni Made Evi Dwi Prihanthini, M. M. (2013). Prediksi kebangkrutan dengan model Grover, Altman Z Score, Springate dan Zmijewski pada perusahaan food and beverage di Bursa Efek Indonesia. E-Jurnal Akuntansi Universitas Udayana.

Ohlson, J. (1980). Financial Ratios and the Probabilistic Prediction of Bankruptcy. Journal of Accounting Research, 18(1), 109-131. doi:10.2307/2490395.

Purnajaya, K. D. M., \& Merkusiwati, N. K. L. A. (2014). Analisis Komparasi Potensi Kebangkrutan Dengan Metode Z-score Altman, Springate, dan Zmijewski Pada Industri Kosmetik Yang Terdaftar di Bursa Efek Indonesia (Comparison Analysis of Bankruptcy Potency With Altman Z-Score, Springate, and Zmijewski Method in Cosmetic Companies That Listed in Indonesia Stock Exchange). E-Jurnal Akuntansi. Vol. 7(1): 48-63.

Putri, E. L. (2018, November 6). Tekan kerugian, Matahari Putra Prima (MPPA) andalkan efisiensi di kuartal IV-2018. Retake from kontan.co.id: https://investasi.kontan.co.id/news/tekankerugian-matahari-putra-prima-mppa-andalkan-efisiensi-di-kuartal-iv-2018

Rahmatullah, M., Sunarya, E., \& Jhoansyah, D. (2019). Analisis Laporan Keuangan dengan Model Z-Score sebagai Alat dalam Memprediksi Bankcruptcy (Studi Kasus pada PT. Ramayana Lestari Sentosa Tbk, PT. Matahari Putra Prima Tbk, dan PT. Mitra Adiperkasa Tbk). Jurnal Riset Inspirasi Manajemen dan Kewirausahaan, 3(1), 22-29. Retake from https://www.researchgate.net/publication/333107015_Analisis_Laporan_Keuangan_de ngan_Model_Z-

Score_sebagai_Alat_dalam_Memprediksi_Bankcruptcy_Studi_Kasus_pada_PT_Ramaya na_Lestari_Sentosa_Tbk_PT_Matahari_Putra_Prima_Tbk_dan_PT_Mitra_Adiperkasa_ Tbk/link/5cdc. 
Bankruptcy Analysis Using Altman Z-Score Model and Springate Model In Retail Trading Company Listed In Indonesia Stock Exchange

Prasetiyani \& Sofyan

Springate, G. L. (1978). Predicting the Possibility of Failure in a Canadian firm. (Unpublished Thesis). British Columbia, Canada: Simon Fraser University.

Tristiawati, P. (2019, Januari 11). 26 Gerai Giant Supermarket Tutup, Hero PHK 532 Pegawai. Retake from liputan6.com: https://www.liputan6.com/bisnis/read/3868947/26-gerai-giantsupermarket-tutup-hero-phk-532-pegawai.

Undang-undang Nomor 4 tentang Kepailitan. (1998). Jakarta.

Zmijewski, M. (1983). Predicting Corporate Bankruptcy: An Empirical Comparison of The Extant Financial Distress Models. Document de travail. State University of New York at Buffalo. 